\title{
Otolith elemental composition and adult tagging reveal spawning site fidelity and estuarine dependency in rainbow smelt
}

\author{
I. R. Bradbury ${ }^{1, *}$, S. E. Campana ${ }^{2}$, P. Bentzen ${ }^{1}$ \\ ${ }^{1}$ Marine Gene Probe Laboratory, Biology Department, Life Sciences Centre, Dalhousie University, Halifax, Nova Scotia, Canada \\ ${ }^{2}$ Population Ecology Division, Bedford Institute of Oceanography, PO Box 1006, Dartmouth, Nova Scotia, Canada
}

\begin{abstract}
Observations of homing and straying in marine organisms based on traditional Eulerian approaches may fail to resolve dispersal kernels or be unable to differentiate homing from invariant local residency. The roles of spawning site fidelity and straying in structuring populations of anadromous smelt Osmerus mordax were examined in coastal Newfoundland through the analysis of otolith elemental composition and a series of adult tagging experiments. Otolith elemental baselines were generated from freshwater residents, estuarine juveniles and laboratory-held individuals (32 psu), using both a single-element (i.e. Sr:Ca and $\mathrm{Ba}: \mathrm{Ca}$ ) and multivariate approach (i.e. discriminant function analysis). Ten spawning fish of unknown dispersal history were sampled from each of 6 spawning locations, and otolith composition was examined using laser ablation inductively coupled plasma mass spectrometry at 12 to 16 locations across each otolith. Single-element and multivariate approaches both indicated estuarine residency predominated, with limited marine $(0.7 \%)$ signatures indicative of rare marine movements. Multiyear spawning site fidelity was examined through a finclipping (2003, $\mathrm{n}=7076$ ) and visual implant elastomer (VIE) experiment (2004, n = 13 524), encompassing each of the 6 spawning locations. We observed limited straying, with 90 to $99 \%$ annual spawning site fidelity. Tag returns declined significantly with distance from location of tagging, and declines were linear over small $(<50 \mathrm{~km})$ distances (VIE: $\mathrm{p}<0.001, \mathrm{r}^{2}=0.99$; fin clipping: $\mathrm{p}<0.001$, $\left.\mathrm{r}^{2}=0.56\right)$. We conclude that population structure in anadromous smelt is maintained by small-scale habitat associations limited to a single estuary, supporting a hypothesis of demographic isolation among estuaries.
\end{abstract}

KEY WORDS: Otolith chemistry $\cdot$ Dispersal $\cdot$ Homing $\cdot$ Rainbow smelt $\cdot$ Population dynamics

\section{INTRODUCTION}

The capacity for homing or site fidelity in mobile marine species may regulate spatial population structure and connectivity (Harden Jones 1968, Hastings \& Botsford 2006). The presence of a pelagic larval stage is often associated with high dispersal potential (Bradbury \& Snelgrove 2001, Shanks et al. 2003); nonetheless, in species with highly mobile adults, straying may significantly contribute to dispersal (e.g. Hendry et al. 2004, Martin \& Wuenschel 2006). Evidence of homing and spawning site fidelity in marine and estuarine species has received limited attention, although several studies suggest site fidelity and philopatry may significantly contribute to spatial patterns in marine species (e.g. Robichaud \& Rose 2001, Thorrold et al. 2001, Ruzzante et al. 2006). The majority of studies on marine dispersal (e.g. Thorrold et al. 2001, Jones et al. 2005) utilize a Eulerian approach, monitoring returns of individuals at a single or a few locations. Such studies characterize homing, but generally fail to describe the extent of movements during the non-measurement periods, fail to delineate the extent of dispersal and, thus, fail to distinguish between homing of adults and invariant small-scale habitat associations. Such a distinction is critical to the identification of the scales of habitat association and the successful management and conservation of marine species. 
Tracking adult dispersal trajectories in marine organisms usually involves either telemetry (e.g. Robichaud \& Rose 2001) or some form of tag (Palumbi 2004, Gillanders 2005). Otolith elemental composition may provide a natural tag reflecting ambient environmental chemistry and allowing reconstruction of dispersal trajectories between habitats differing in composition (e.g. Campana 1999, Secor \& Rooker 2000, Elsdon \& Gillanders 2003). Most commonly, changes in single-element composition along a growth axis (e.g. $\mathrm{Sr}: \mathrm{Ca}$ and $\mathrm{Ba}: \mathrm{Ca}$ ) have been shown to reflect ambient salinity and allow reconstruction of migration history in diadromous or estuarine species (e.g. Thorrold et al. 1997, Elsdon \& Gillanders 2005a,b, Gillanders 2005). As such, a positive association between otolith elemental Sr:Ca and salinity due to increased ambient $\mathrm{Sr}: \mathrm{Ca}$ concentrations seems well established (e.g. Secor \& Rooker 2000). Further work suggests a negative relationship between elemental $\mathrm{Ba}: \mathrm{Ca}$ concentrations and salinity (e.g. Thorrold et al. 1997, Elsdon \& Gillanders 2005a), which may be equally useful in reconstructing movements along a salinity gradient. However, regional differences in ambient chemistry can result in weak single-element gradients among habitats (e.g. Kraus \& Secor 2004); thus, multivariate approaches may provide increased discriminatory power (e.g. Campana et al. 1999, Hamer et al. 2005).

Rainbow smelt Osmerus mordax (Mitchill) is a small pelagic fish found in coastal and freshwater systems throughout north-eastern North America (Nellbring 1989). Anadromous smelt spawn near the head of the tide in coastal rivers and streams, and the larvae develop in downstream estuaries (e.g. Ouellet \& Dodson 1985, Bradbury et al. 2004, 2006a). Prior work suggests significant contributions of behaviour to early life-history patterns in the form of synchronized hatching (Bradbury et al. 2004) and active estuarine retention of larvae (Laprise \& Dodson 1989, Bradbury et al. 2006a). Limited small-scale tagging studies suggest high rates of annual fidelity to spawning locations $(95 \%)$ and increased straying among spawning locations within a local estuary (McKenzie 1964). Nonetheless, non-reproductive movements of 100 to $300 \mathrm{~km}$ have been measured within the St. Lawrence estuary (Magnin \& Beaulieu 1965) and indicate potential broad-scale straying.

The overall goal of this work was to elucidate the role of adult movements' in the maintenance of smelt population structure. The specific objectives were (1) to reconstruct adult movements between the local estuary and the coastal ocean using otolith elemental composition to reconstruct movements, (2) to examine annual spawning fidelity to spawning locations over a $2 \mathrm{yr}$ period using tagging of adults, and finally (3) to compare estimates of movement from otolith-based and tag-based approaches. Although each component (e.g. otolith microchemistry, adult tagging) was designed and implemented independently, this novel pairing of otolith-based reconstructions with Eulerian-based tagging experiments provides a uniquely comprehensive description of adult movements and dispersal.

\section{MATERIALS AND METHODS}

Study locations. The study area encompassed 2 large coastal embayments (Placentia and St. Mary's Bays). Local hydrography is dominated by a counterclockwise flow generated from an inshore branch of the Labrador Current, which enters both bays to the east and exists at the western boundary (see Bradbury et al. 2000 for details). Smelt Osmerus mordax spawning locations throughout Placentia and St. Mary's Bays were identified through visual surveys and interviews with local residents. Smelt spawning migrations begin in mid-April and continue until late June across the study area. Six spawning locations were chosen (Fig. 1), 5 in St. Mary's Bay and 1 in Placentia Bay. These spawning locations differed significantly in estuarine structure, from that of an inland fjord open to the coast for only weeks at a time (i.e. Holyrood Pond) to barred estuaries with continuous access (i.e. Biscay Bay and Southeast Placentia) to open non-restricted estuaries (i.e. Salmonier and Colinet). Fish were obtained using dip or fyke nets during the spawning periods in 2003 to 2005. Samples for otolith chemistry were primarily 3 yr old fish, with the exception those from Holyrood Pond, where spawning fish were all 2 yr old.

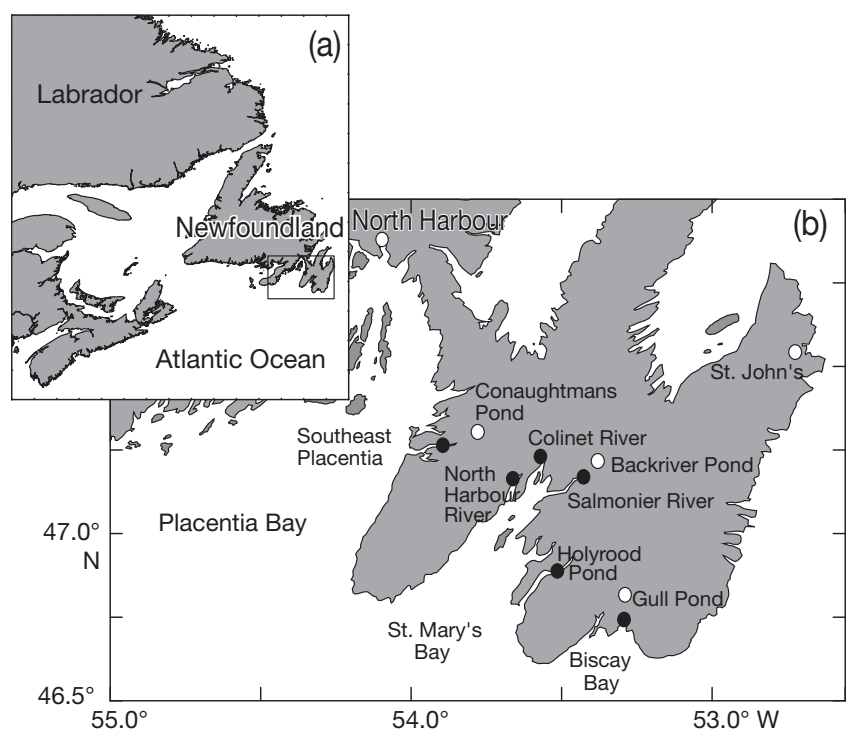

Fig. 1. Study area (a) with respect to eastern Canada, showing (b) study locations on the southeast coast of Newfoundland. O: baseline sample locations; $\bullet$ : sampled anadromous smelt spawning locations 
Otolith collection and handling. Sagittal otoliths were extracted from 10 randomly selected spawning adults from each of the 6 spawning locations. To allow assignment of microchemical signatures to specific habitat types, otolith baseline samples were also collected from a variety of salinity regimes. The choice of baseline salinities was made using previous measures of salinity in each of the spawning freshwater $(0 \pm$ $0.00 \mathrm{psu})$, estuarine (7.6 $\pm 7.39 \mathrm{psu})$ and marine habitats (30.4 $\pm 0.60 \mathrm{psu})$ (authors' unpubl. data). Freshwater otolith chemistry baseline data were acquired using otoliths from smelt inhabiting 3 freshwater ponds distributed across the study range (Fig. 1). Given the difficulty in adequately characterizing the estuarine baseline due to the dynamic nature of estuarine hydrography, the estuarine baseline was chosen to represent the upper range of salinities encountered in estuaries across the study area. The estuarine otolith baseline sample was obtained from juveniles sampled at North Harbour Placentia Bay (October 2004), which is characterized by an average salinity of $\sim 22 \mathrm{psu}$. A marine otolith baseline was obtained from fish held at the Ocean Sciences Center for 1 yr (2003 to 2004) in ambient seawater (i.e. 32 psu). In all baseline samples, 10 individuals were analyzed. All otoliths were cleaned using Super Q water and stored in acidwashed polypropylene vials. Otoliths were embedded in epoxy and sectioned to a width of $400 \mu \mathrm{m}$ using an Isomet saw. Sections were imaged, aged, and the width of each consecutive annulus was measured using ImagePro software. Annulus widths were compared among habitats using fixed-variable analysis of variance (ANOVA) to detect regional differences in growth. In individuals where the first annulus was unclear, the approximate width of the first annulus was confirmed using a sample of 1 yr old fish taken from Biscay Bay estuary in June 2004.

Microchemical analysis. Otolith elemental composition was measured using laser ablation inductively coupled plasma mass spectrometry (LA-ICP-MS). All assays were conducted at WRL laboratories at Arkansas State University (for further information see Coghlan et al. 2007). A CETAC LSX500 (260 nm) laser coupled to a Perkin-Elmer SCIEX DRCII Dynamic Reaction Cell ICP-MS was used to ablate otoliths under consistent operating parameters $(20 \mathrm{~Hz}, 600$ shots, $100 \%$ energy). Instrument gas flow and lens voltage were adjusted each day to maximize instrument sensitivity and performance (i.e. maximizing element detection while minimizing count variability), and gas blanks (Ar) were run prior to each acquisition. All assays were done with a $25 \mu \mathrm{m}$ spot size, but, as preliminary analysis indicated a large amount of smallscale heterogeneity in otolith composition, 3 replicates were taken per sample along a growth zone. Using the
Digi-Laz software, 2 samples were taken equally spaced across the growth axis in each summer and winter band along a path chosen to be free of abnormalities (e.g. fractures), which may influence analysis. In the estuarine and marine baseline samples, only the edge of the otolith was assayed, as this was the region of the otolith associated with the habitat of interest. As the various baselines examined were of different developmental stages, the presence of any ontogenetic variation was examined in the freshwater baseline. Assays were conducted along the growth axis at the core, middle (equidistant between the edge and core) and edge (3 replicates of each) to examine ontogenetic variation under constant salinity.

A standard reference material, micro-analytical carbonate standard 1 (MACS-1, United States Geological Survey), was used to calibrate and control for drift every 5 to 9 samples. Concentration of analytes was determined by 1-point calibration using FEBS-1 (CRM, otolith). Analysis revealed many detectable elements, but ${ }^{86} \mathrm{Sr}$ and ${ }^{136} \mathrm{Ba}$ were chosen as previous work (Secor \& Rooker 2000, Gillanders 2005) suggests direct linkages to ambient concentrations. We used Geo-Pro software (Cetac Technologies) to integrate ICPMS data and estimate corresponding concentrations of $\mathrm{Sr}, \mathrm{Ba},{ }^{42} \mathrm{Ca}$ and ${ }^{43} \mathrm{Ca}$. Calibration was based on external standardization with internal calibration. ${ }^{42} \mathrm{Ca}$ was used as an internal standard and is $38 \%$ by weight in MACS-1 and otoliths, and we measured ${ }^{43} \mathrm{Ca}$ to estimate total Ca. Accuracy was determined using comparison to MACS-1, with measured values being within $5 \%$ of those known, and precision was measured through replicate analysis with repeated measures being between 2 and $3 \%$ relative SD. The limit of detection was estimated as 3 -fold the standard deviation for 7 blank replicates for each of the analytes. Limits of detection for each element were as follows - Sr: $12.13 \mathrm{ppm}$; Ba: $37.62 \mathrm{ppb}$; and Ca: 102 ppm. Data analysis followed Campana (2005). To control for the amount of ablated material, all concentrations were expressed in comparison to ${ }^{43} \mathrm{Ca}$. Elemental ratios $>2$-fold the standard deviation from the global mean were removed from further analysis as they likely represent contamination.

To assign samples as 1 of the 3 baselines (freshwater, estuarine, marine) 2 approaches were used. First, unknown sample to baseline comparisons were made using $\mathrm{Sr}: \mathrm{Ca}$ and $\mathrm{Ba}: \mathrm{Ca}$ and the averages for the various baseline (i.e. known salinity) groups. Transects across the otolith for each individual were plotted in comparison to baseline data. Second, we used a linear discriminant function analysis (DFA) using $\mathrm{Sr}$ :Ca and Ba:Ca to assign unknown samples to a baseline group. For DFA, multivariate assumptions such as data normality and the presence of outliers were examined using fre- 
quency histograms; transformation was not required. The presence of otolith baseline differences among salinity regimes was examined for each element using fixed-variable ANOVA prior to DFA, to ensure differences were sufficient to allow discrimination. Differences within individual otoliths in single elements and DFA scores were examined using repeated-measures ANOVA (SYSTAT V.11). Furthermore, to examine any influence of ontogeny on DFA-based assignment, the freshwater baseline for the DFA was established using the core, middle and edge portions separately, and the remaining otolith regions were treated as unknowns and assigned as above.

To validate the interpretation of otolith composition reflecting ambient concentrations, a $50 \mathrm{ml}$ water sample was collected from each of the baseline habitats, spawning locations, estuaries and associated marine habitats, and subsequently analyzed for elemental composition. All samples were collected from 1 $\mathrm{m}$ below the surface in the summer and fall of 2004, and temperature and salinity were recorded using a YSI 30. Water samples were acidified with ultrapure nitric acid, and subsequently analyzed for trace element concentrations. Samples were analyzed by inductively coupled plasma emission spectrometry (ICP-ES) (Varian Vista Pro) and inductively coupled plasma mass spectrometry (ICP-MS) (Thermo XSeries). The methods have been adapted from EPA Method 200.7 (ICP-ES) and EPA Method 200.8 (ICPMS). Multi-element calibration standards were prepared from $1000 \mathrm{mg} \mathrm{l}^{-1}$ reference solutions, and original stocks are NIST-Traceable.

Tagging experiments. Two tagging experiments were conducted during the spawning periods, in 2003 and 2004, with recoveries in subsequent years. In 2003, 7076 fish were tagged by fin clipping (following McKenzie 1964) at each of the 6 spawning locations. As some fin re-growth is expected, fin clipping in- volved the complete removal of pelvic or pectoral fins (McKenzie 1964), the combination of which allowed for site-specific tags. Recoveries were made through visual examination in 2004 at each of the tagging locations during the annual spawning season (Table 1). Mortality of smelt associated with fin clipping has been estimated at $<5 \%$, and re-growth of the fin is assumed to be negligible over the time period of interest (McKenzie 1964). Though not examined, the presence of false positives in the fin-clipping experiment was assumed negligible, as natural fin loss was easily differentiated in the field from complete removal.

In 2004, 13524 smelt were tagged using visual implant elastomer (VIE), and recoveries were again made the following year (i.e. 2005) at each of the tag locations, as well as at the additional spawning site within Holyrood Pond (i.e. Path End). VIE tagging was accomplished through the injection of a $1 \mathrm{~cm}$ line of elastomer into the adipose tissue located behind the eye. Three colours and alternating sides of head allowed for spawning-site differentiation. VIE tag retention and mortality was estimated using 100 smelt tagged at Salmonier River and held at the Ocean Sciences Center of Memorial University Newfoundland from May 28, 2004 to May 12, 2005. Fish were held in $1 \mathrm{~m}^{3}$ tanks, fed to satiation, and kept at ambient seawater temperature. Both tag loss and tag mortality was $<5 \%$ over 1 yr in captivity and support the utility of this approach in tagging smelt. To assess tag loss in non-laboratory environments, fish at 1 location (i.e. North Harbour, St. Mary's Bay) were double tagged (i.e. on both sides of the head) and subsequent recoveries allowed estimates of tag loss. Although tag loss through differential mortality of tagged fish has been noted elsewhere (Catalano et al. 2001), it seems uncommon in mature fish and any effect would likely be minimal (e.g. Roberts \& Kilpatrick 2004).

Table 1. Numbers of smelt Osmerus mordax tagged using fin clipping (2003) and visual implant elastomer (VIE, 2004) and examined for tags (2004 to 2005). See 'Materials and methods' for experiment details

\begin{tabular}{|c|c|c|c|c|c|c|}
\hline \multirow{2}{*}{ Location } & \multicolumn{3}{|c|}{ Fin clipping } & \multirow{2}{*}{$\begin{array}{l}\text { No. tagged with } \\
\text { VIE (2004) }\end{array}$} & \multirow{2}{*}{$\begin{array}{l}\text { Tagging } \\
\text { Examined } \\
(2005)\end{array}$} & \multirow[b]{2}{*}{$\begin{array}{c}\text { Total } \\
\text { recaptured }\end{array}$} \\
\hline & $\begin{array}{l}\text { No. fin clipped } \\
\text { (2003) }\end{array}$ & $\begin{array}{c}\text { Examined } \\
(2004)\end{array}$ & $\begin{array}{c}\text { Total } \\
\text { recaptured }\end{array}$ & & & \\
\hline \multicolumn{7}{|l|}{ St. Mary's Bay } \\
\hline Salmonier River & 1942 & 4157 & 53 & 5049 & 8864 & 457 \\
\hline Colinet River & 1578 & 4107 & 90 & 4069 & 7733 & 321 \\
\hline North Harbour & 479 & 358 & 13 & 534 & 655 & 40 \\
\hline Holyrood Pond & 930 & 1000 & 0 & 1523 & 9199 & 28 \\
\hline Biscay Bay & 850 & 550 & 6 & 560 & 295 & 0 \\
\hline \multicolumn{7}{|l|}{ Placentia Bay } \\
\hline Southeast Placentia & 1297 & 1449 & 16 & 1789 & 1958 & 180 \\
\hline Totals & 7076 & 10621 & 178 & 13524 & 28704 & 1026 \\
\hline
\end{tabular}




\section{RESULTS}

\section{Otolith elemental composition}

Ambient water concentrations of $\mathrm{Ba}: \mathrm{Ca}$ and $\mathrm{Sr}: \mathrm{Ca}$ differed among each of the baseline treatments (i.e. freshwater, estuarine, marine; Fig. 2). Sr:Ca displayed a positive association, and Ba:Ca a significant negative association with salinity (Fig. 2). The composition of baseline water samples corresponded with the averages of water samples taken from each of the river, estuarine and marine habitats sampled for smelt, supporting the representative nature of these baseline samples (Fig. 2). Moreover, positive associations were observed among baseline otolith samples and ambient water concentrations (Sr: $\mathrm{p}<0.001, \mathrm{R}^{2}=0.86$, df $=4$; Ba: $\mathrm{p}<0.001, \mathrm{R}^{2}=0.93$, df $=4$; Fig. 3a,b). Singleelement ANOVAs suggested significant differences among baselines (Sr:Ca: $\mathrm{p}<0.001$, df = 113; Ba:Ca: $\mathrm{p}<$ 0.001 , df $=113$ ). DFA of baseline samples produced a single axis (DFA1), which allowed $97 \%$ correct assignment of samples (Fig. 3c). The majority (86\%) of DFA1 scores for the marine baseline were less than -4 , which
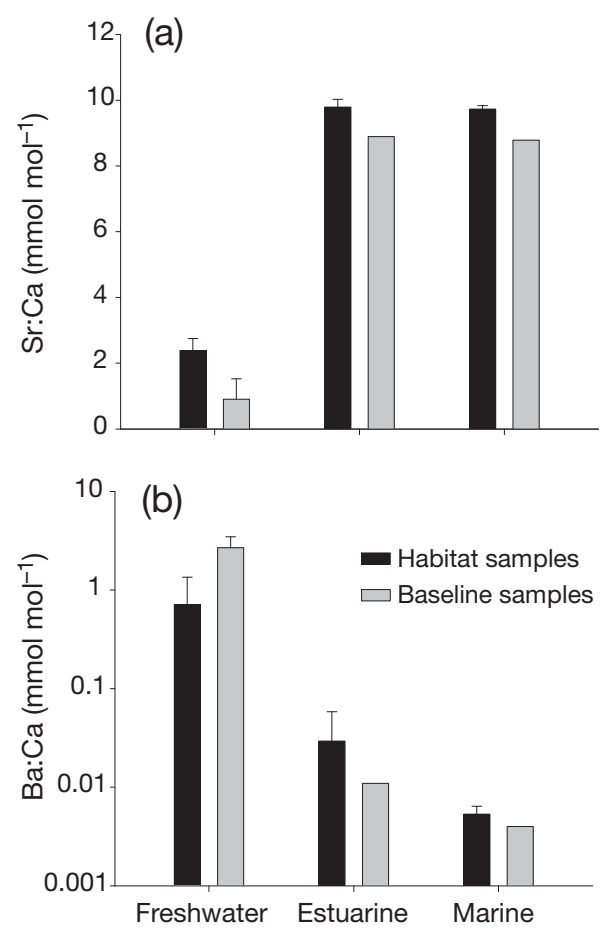

Fig. 2. Ambient water (a) $\mathrm{Sr}: \mathrm{Ca}$ and (b) Ba:Ca for all river $(0 \mathrm{psu}, \mathrm{n}=6)$, estuary $(7.6 \pm 7.3 \mathrm{psu}, \mathrm{n}=6)$ and marine $(30.4 \pm$ $0.60 \mathrm{psu}, \mathrm{n}=6$ ) locations sampled, as well as salinity baseline locations (i.e. pond, estuarine and laboratory-held marine samples) for otolith composition. See 'Materials and methods' for details regarding each treatment. All concentrations are expressed as ratios to ${ }^{43} \mathrm{Ca}$ and were averaged across locations within a habitat type; error bars represent standard deviations was subsequently used as a conservative transition between estuary and marine residency.

Single-element trends in $\mathrm{Sr}: \mathrm{Ca}$ and $\mathrm{Ba}: \mathrm{Ca}$ ratios across the otoliths at each of the 6 spawning locations generally displayed concentrations indicative of estuarine baseline levels (Sr:Ca and Ba:Ca; Figs. 4 \& 5, respectively). At all spawning locations, values of $\mathrm{Sr}$ : $\mathrm{Ca}$ and $\mathrm{Ba}$ :Ca varied significantly across otoliths (repeated-measures ANOVA: Sr: $p=0.003$, df = 13; Ba: $\mathrm{p}<0.001$, df = 13). Furthermore, differences among various estuarine habitats seem associated with local
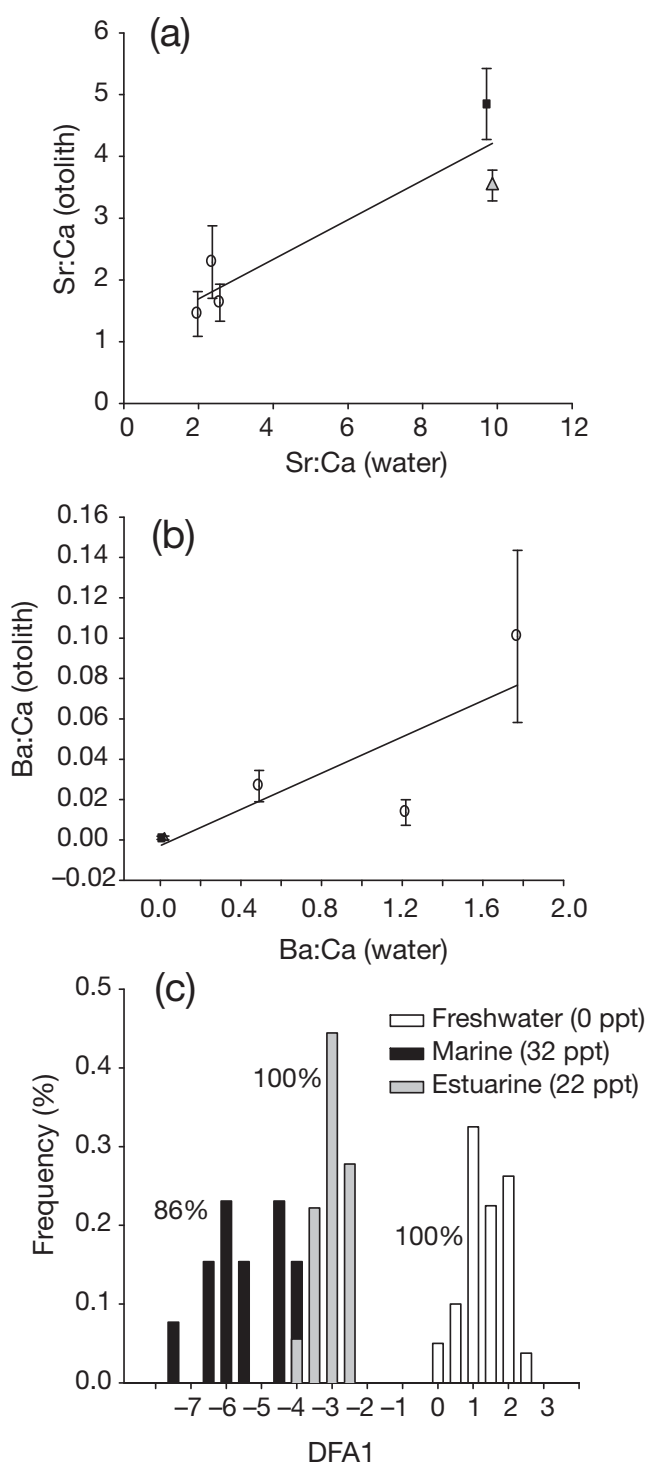

Fig. 3. Osmerus mordax. Relationship between average ambient water concentrations and baseline otolith concentrations $( \pm \mathrm{SE})$ of (a) Sr:Ca and (b) Ba:Ca. (c) Otolith first discriminant function axis (DFA1) for 3 salinity baselines - black: marine; grey: estuarine; white: freshwater. See 'Materials and methods' for details regarding each treatment. All concentrations are expressed as molar concentration ratios to ${ }^{43} \mathrm{Ca}$ 
(a) Salmonier River

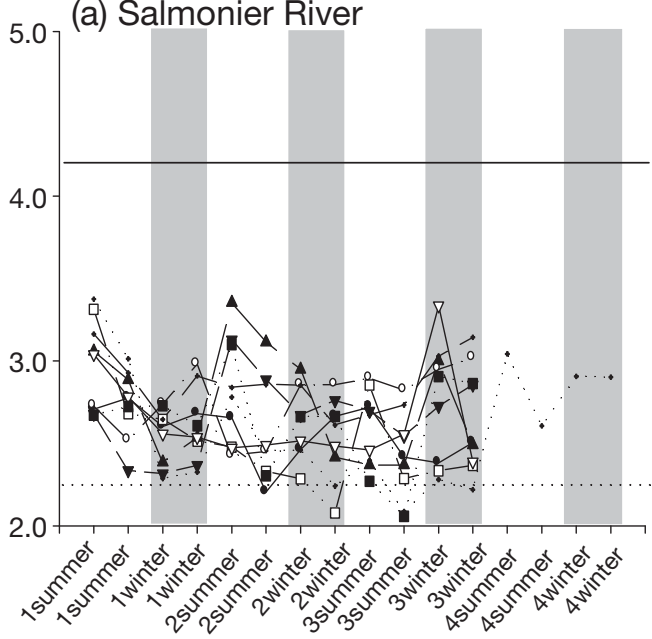

(b) Biscay Bay
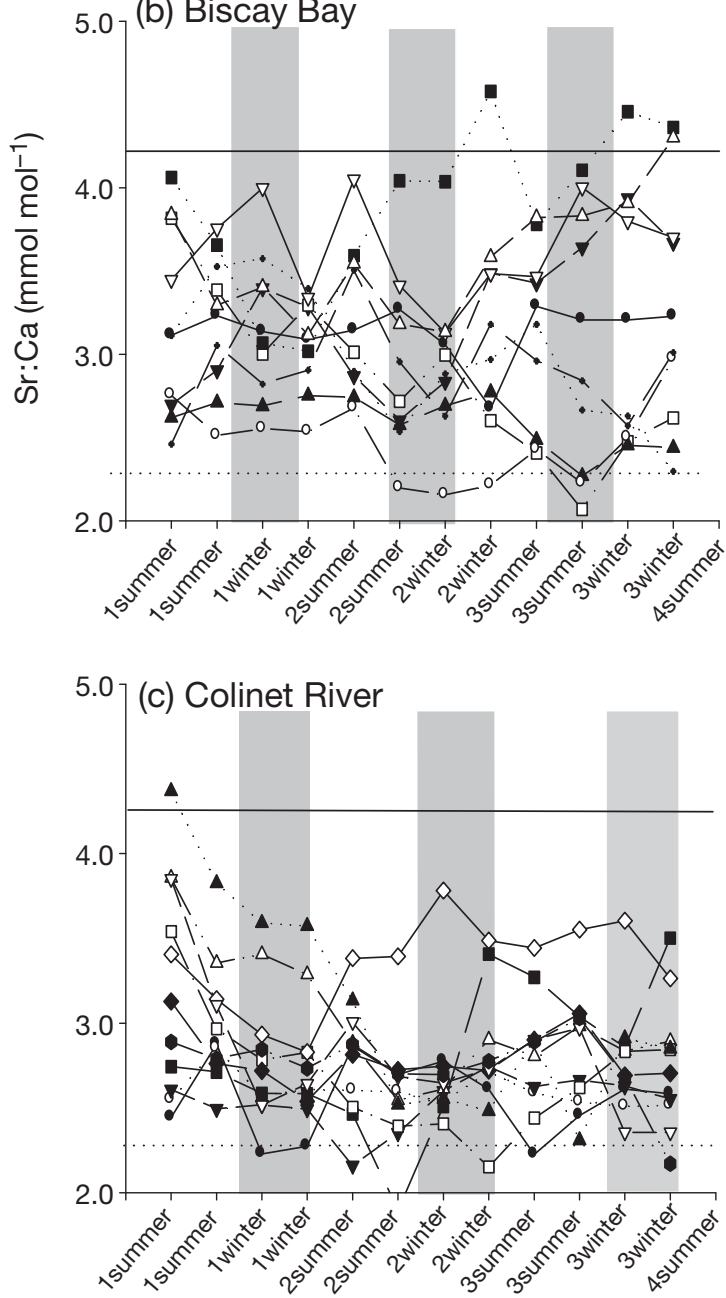

(d) Holyrood Pond
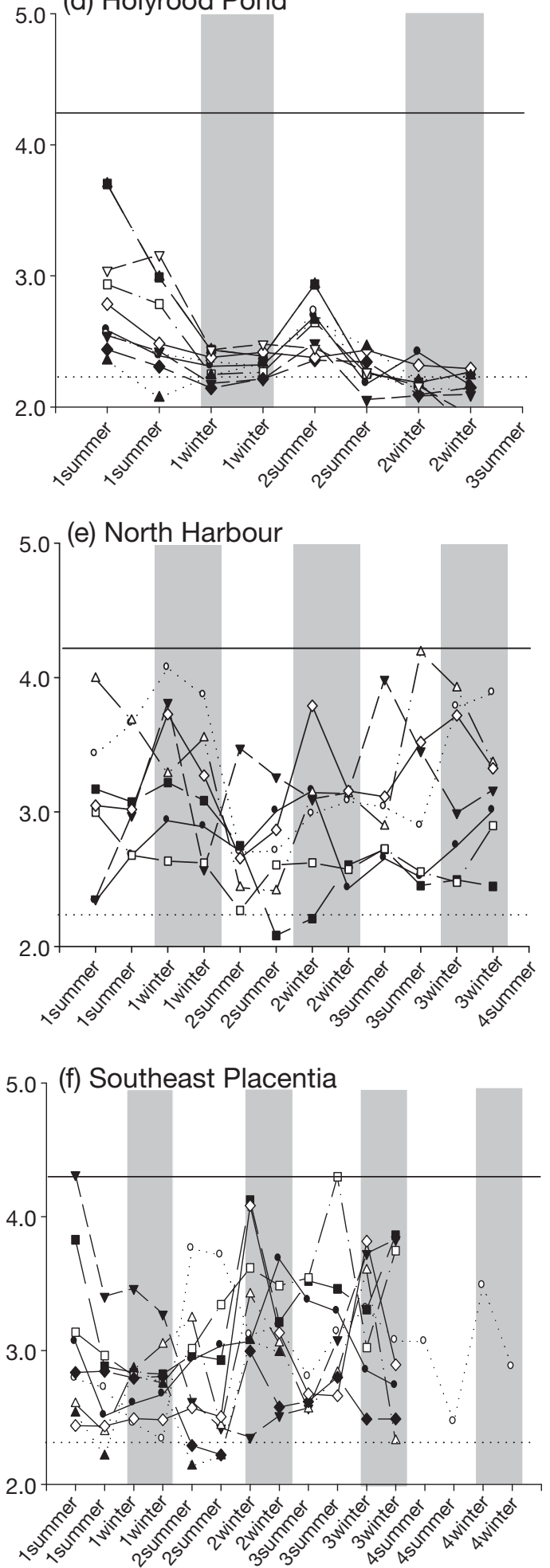

Otolith assay location

Fig. 4. Transects of Sr:Ca across rainbow smelt Osmerus mordax otoliths from 6 spawning locations (a to f) throughout southeastern Newfoundland. Horizontal lines: threshold values for a greater probability of being assigned to a given habitat, i.e. the mean of a habitat $( \pm \mathrm{SD})$; solid line: average marine value $(-\mathrm{SD})$; dotted line: average freshwater baseline $(+\mathrm{SD})$; shaded bars: winter portions of each otolith. See Fig. 2 for further otolith baseline data (e.g. estuarine baseline) and Fig. 1 for sample locations. Each transect (i.e. symbol type) represents the average values across replicates $(n=3)$ of a single individual 
(a) Salmonier River

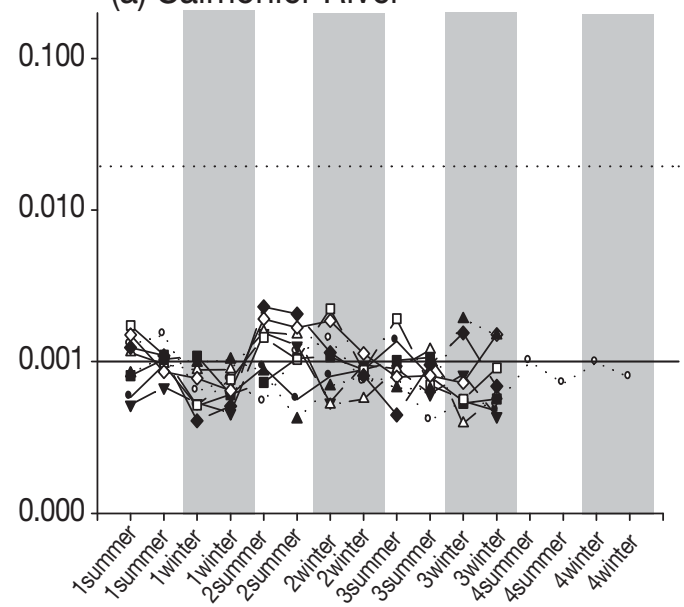

(b) Biscay Bay

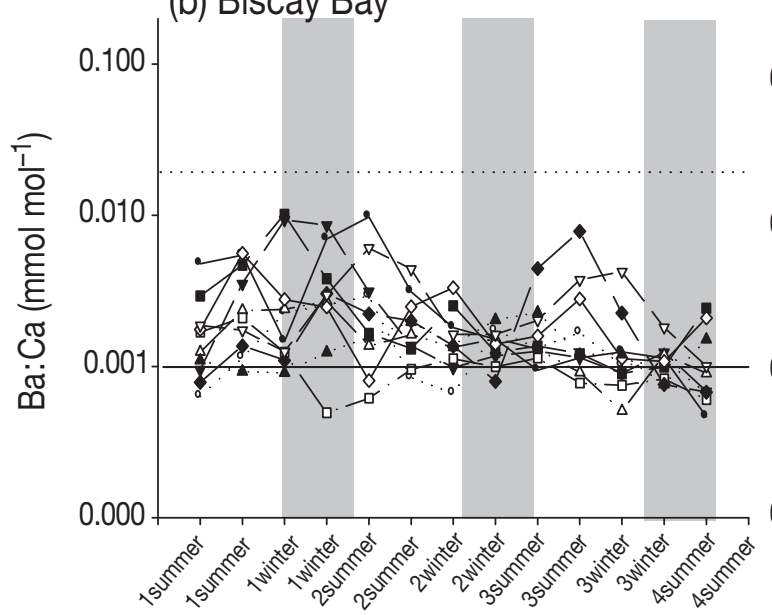

(c) Colinet River

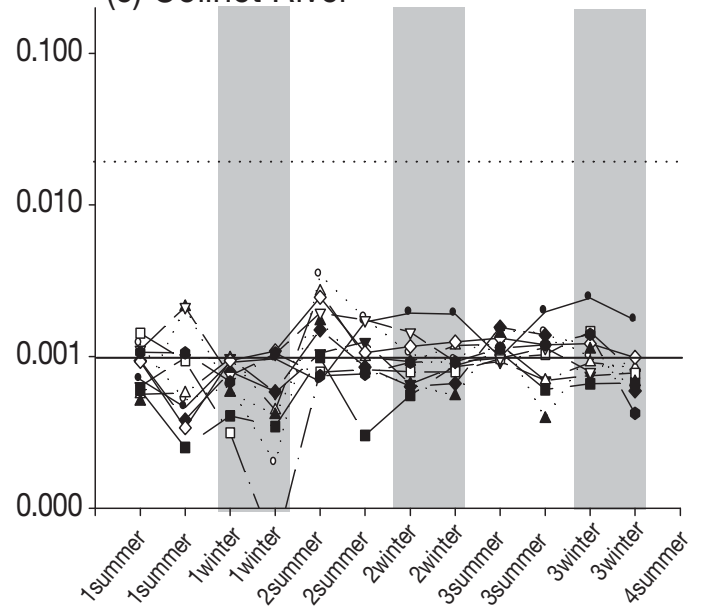

(d) Holyrood Pond

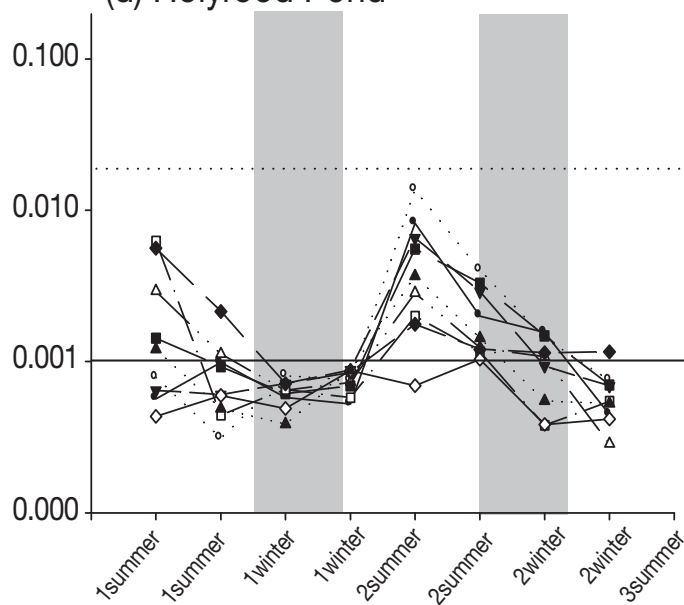

(e) North Harbour
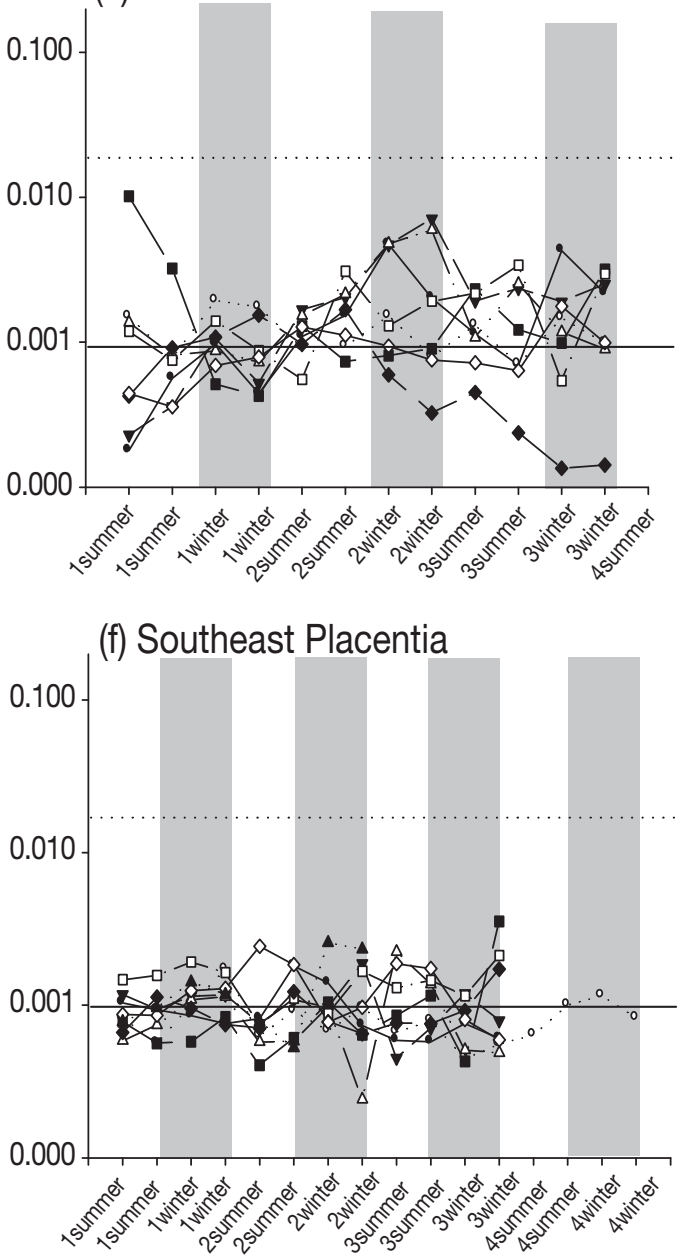

\section{Otolith assay location}

Fig. 5. Transects of Ba:Ca across rainbow smelt Osmerus mordax otoliths from 6 locations (a to f) throughout south-eastern Newfoundland. Horizontal lines: threshold values for a greater probability of being assigned to a given habitat, i.e. the mean of a habitat $( \pm \mathrm{SD})$; solid line: average marine value $(-\mathrm{SD})$; dotted line: average freshwater baseline $(+\mathrm{SD})$; shaded bars: winter portions of each otolith. See Fig. 2 for further otolith baseline data (e.g. estuarine baseline) and Fig. 1 for sample locations. Each transect (i.e. symbol type) represents the average values across replicates $(n=3)$ of a single individual 
Table 2. Results of discriminant function analysis (DFA) and assignments of unknown migration history samples based on freshwater, estuarine, or marine baselines. See 'Materials and methods' for assay and baseline details. Numbers represent the number of individual assays assigned, and values in parentheses represent the percent classification

\begin{tabular}{|lccccc|}
\hline \multirow{2}{*}{ Location } & \multirow{2}{*}{$\begin{array}{c}\text { Total } \\
\text { samples }\end{array}$} & $\begin{array}{c}\text { Fresh- } \\
\text { water }\end{array}$ & Estuarine & Marine \\
& & & & \\
\hline Biscay Bay & 121 & $3(2.5 \%)$ & $115(95 \%)$ & $3(2.5 \%)$ \\
Salmonier River & 103 & $10(9.7 \%)$ & $93(90.3 \%)$ & $0(0 \%)$ \\
Colinet River & 132 & $16(12.1 \%)$ & $116(87.9 \%)$ & $0(0 \%)$ \\
North Harbour & 80 & $7(8.8 \%)$ & $72(90 \%)$ & $1(1.2 \%)$ \\
Holyrood Pond & 67 & $26(38.8 \%)$ & $41(61.2 \%)$ & $0(0 \%)$ \\
SE Placentia & 108 & $6(5.6 \%)$ & $102(94.4 \%)$ & $0(0 \%)$ \\
\end{tabular}

estuarine structure. The partially landlocked anadromous sample (i.e. Holyrood Pond) displayed very little variation among individuals, and was consistently furthest from the marine signature (Figs. 4 \& 5). Estuaries with no sand bar (i.e. Salmonier, Colinet) displayed more individual variation, yet values were generally consistent across the otoliths. In contrast, the 2 locations characterized by sand bars dividing the estuary into low- and high-salinity regimes (Biscay Bay and Southeast Placentia) displayed much greater variation among individuals and across a given otolith transect (Figs. 4 \& 5).

Assignment of unknown samples based on the DFA analysis identified the majority of samples as estuarine $(\sim 90 \%)$, with $10 \%$ freshwater assignment, and $<1 \%$ marine (Table 2, Fig. 6) and was consistent with singleelement trends. Most of the freshwater assignments were associated with the landlocked site, Holyrood Pond (Table 2). Only Biscay Bay and North Harbour (both barred estuaries) possessed any positive assignments for a marine signature, with a total of 3 individuals being assigned to the marine baseline. As observed above in the single-element data, DFA axis values significantly varied across otoliths (repeated-measures ANOVA, $\mathrm{p}=0.004, \mathrm{df}=13$ ). Again Holyrood Pond showed little variation among individuals or across transects. Moreover, barred estuaries displayed much greater variation than open estuaries both among individuals and along each otolith transect (Fig. 6).

Potential biases of otolith elemental composition associated with site-specific growth rate or ontogeny were evaluated in several ways. First, we assessed growth rate differences across all spawning locations through a comparison of annulus width. We observed no significant differences across the study area in growth in Year 1 using ANOVA and the width of each annulus ( $p=0.13, d f=60)$, in Year $2(p=0.12, d f=60)$, or in Year $3(p=0.40, d f=50)$. Second, repeated- measures ANOVA comparing the core, middle and edge of the freshwater baseline otoliths (i.e. freshwater ponds with no sea access) indicated consistent differences in both $\mathrm{Sr}: \mathrm{Ca}(\mathrm{p}=0.035, \mathrm{df}=2)$ and $\mathrm{Ba}: \mathrm{Ca}$ $(\mathrm{p}<0.000, \mathrm{df}=2)$, with ontogeny in all freshwater habitats. However, we repeated the DFA analysis above using the core, middle, or edge of the freshwater baseline and assigning the remaining otolith regions as freshwater, estuarine, or marine. We observed complete $(100 \%)$ agreement among assignments irrespective of which otolith region constituted the freshwater baseline. Finally, a comparison of DFA1 between the first year and subsequent years at the partially landlocked anadromous location (i.e. Holyrood Pond) suggests no significant difference in assignment due to ontogenetic differences in growth rate or development (ANOVA, $\mathrm{p}=0.53$ ).

\section{Tagging experiments}

The number of fish tagged ranged from 7076 fish fin clipped in 2003 to 13524 fish tagged with VIE in 2004. The proportion of double VIE-tagged returns to the North Harbour site was $~ 92 \%$, suggesting a similar tag retention to that observed in the laboratory experiment. In both recovery years (2004 and 2005), most returns were at the location of tagging (Fig. 7). The only exception was in 2005, when a significant portion of strays were detected between the 2 spawning locations within Holyrood Pond (i.e. Path End and Holyrood Pond Park; Fig. 8). The proportion of straying was higher with the fin-clipping $(\sim 10 \%)$ experiment than with VIE $(\sim 1 \%)$. In both experiments, the proportion of returns declined significantly with distance from tagging location (Fig. 7). In the fin-clipping experiment a significant geographic decline was observed at scales $<30 \mathrm{~km}$; however, significant straying was observed up to scales of $140 \mathrm{~km}$. In contrast, the maximum straying detected with the VIE experiment was $26 \mathrm{~km}$ (Fig. 7).

Temporal trends in the distribution of returns could bias recoveries to lower values if surveys missed returning fish. We observed continual seasonal declines in returns in 2004, consistent with an age-structured spawning season (Fig. 8). This did not appear to be related to the abundance available for sampling, as numbers observed seemed unrelated to day of capture. However, we did observe declines in fork length at 3 spawning locations where fish were measured, suggestive of a seasonal decline in age of spawners. Mean size at the start was, on average, $210 \mathrm{~mm}$ and declined to $\sim 180 \mathrm{~mm}$ by the end of the season. However, as this was explored in 2004, and a decrease in returns over long distances was detected in 2004, this does not explain the difference among years. 
(a) Salmonier River

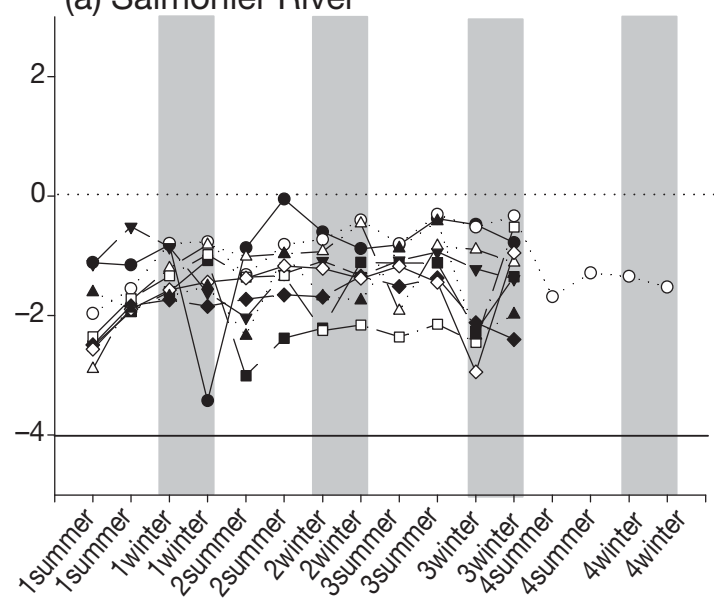

(b) Biscay Bay

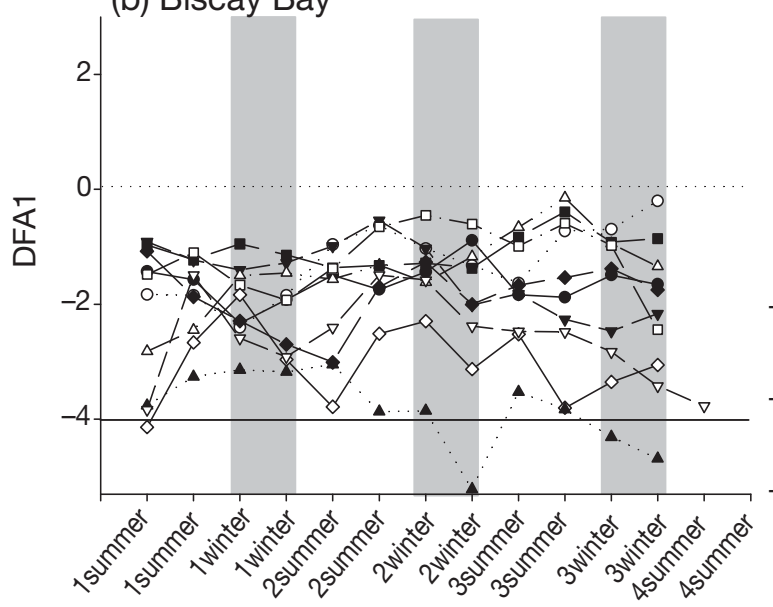

(c) Colinet River

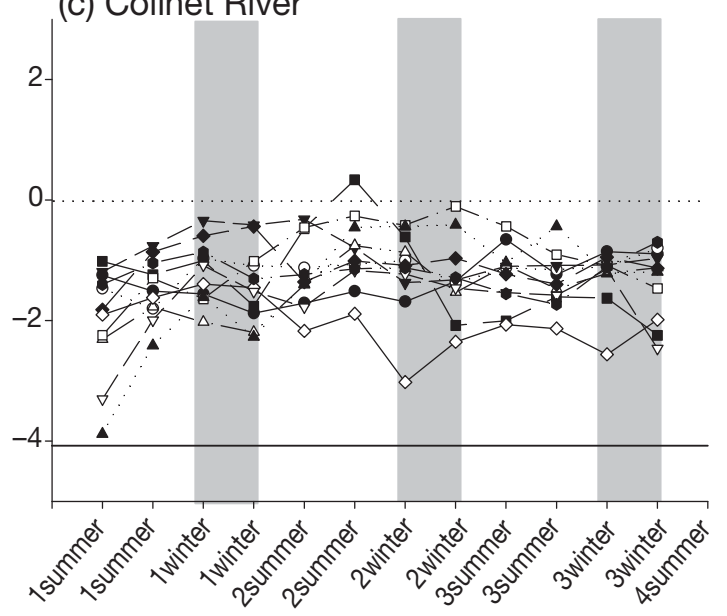

(d) Holyrood Pond

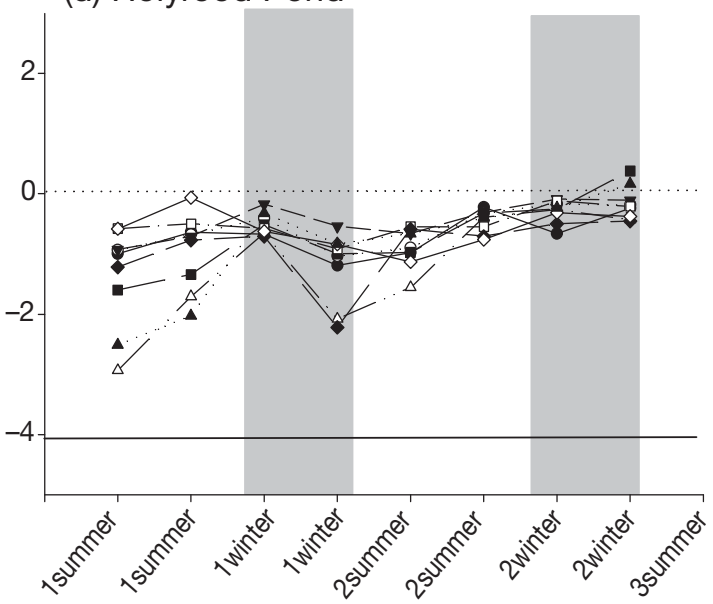

(e) North Harbour
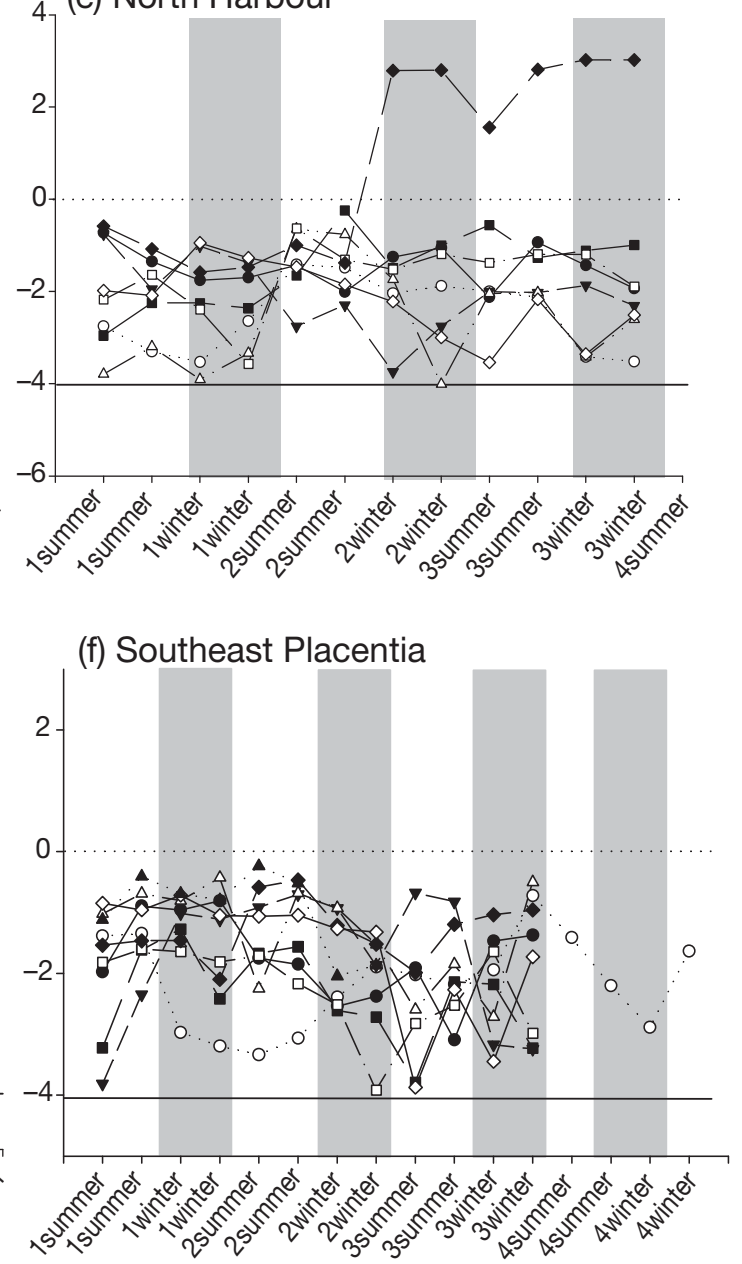

Otolith assay location

Fig. 6. Transects of the first axis of the discriminant function analysis (DFA1) across rainbow smelt Osmerus mordax otoliths from 6 locations (a to f) throughout south-eastern Newfoundland. Horizontal lines: threshold values for a greater probability of being assigned to a given habitat, i.e. the mean of a habitat $( \pm \mathrm{SD})$; solid line: average marine value $(-\mathrm{SD})$; dotted line: average freshwater baseline (+SD); shaded bars: winter portions of each otolith. See Fig. 2 for further otolith baseline data (e.g. estuarine baseline) and Fig. 1 for sample locations 

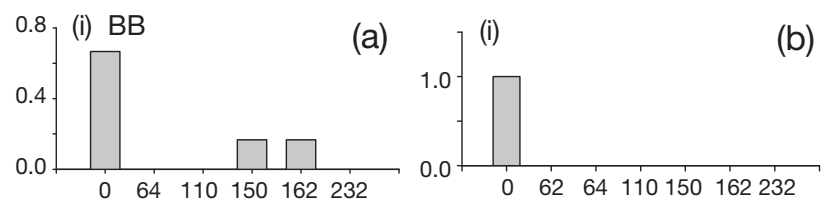

(ii) PATH no data
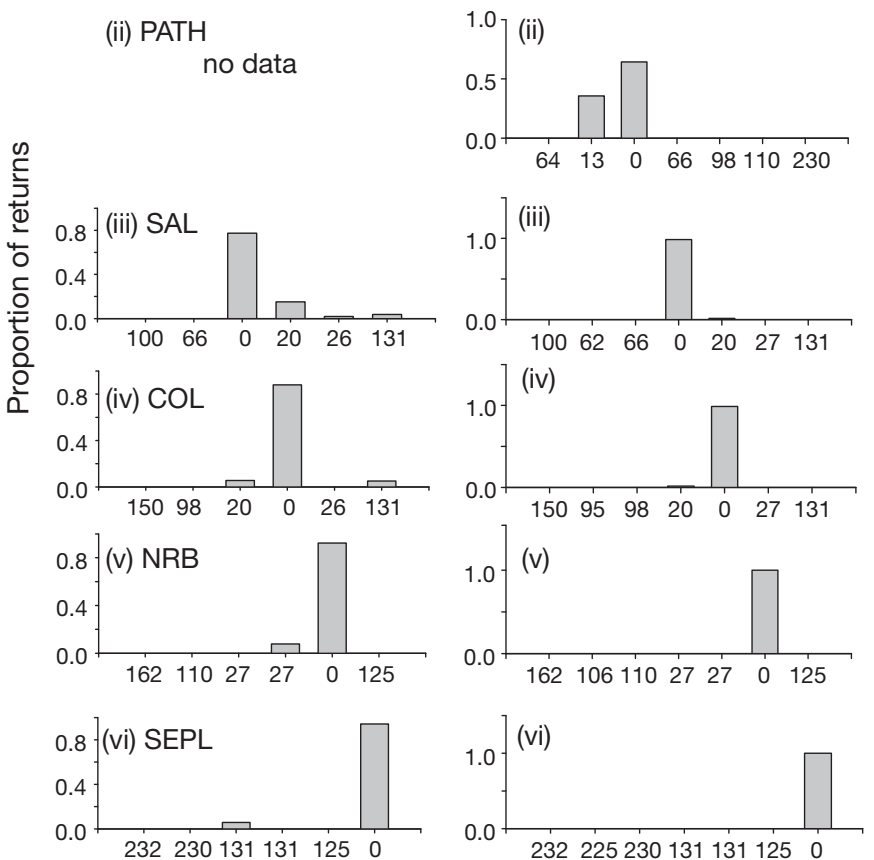

Distance recaptured from tag location $(\mathrm{km})$

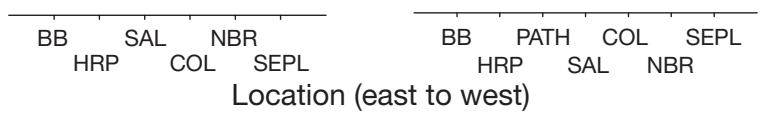

Fig. 7. Osmerus mordax. Frequency of returns from tagging experiments in (a) 2003 (fin clipping) and (b) 2004 (visual implant elastomer) at 6 spawning locations (i to vi) throughout south-eastern Newfoundland. See Fig. 1 for tagging locations. BB: Biscay Bay; HRP: Holyrood Pond; PATH: Pathend (also Holyrood Pond); SAL: Salmonier River; COL: Colinet River; NBR: North Harbour; SEPL: Southeast Placentia

\section{DISCUSSION}

Metapopulation dynamics in highly mobile marine animals are partly dependent on adult spatial ecology and the capacities for homing and philopatry (Palumbi 2004). Despite the potential for large-scale movements (e.g. Magnin \& Beaulieu 1965), we observed high rates of spawning-site fidelity and estuarine-restricted dispersal in anadromous rainbow smelt Osmerus mordax consistent with the formation of localized discrete populations. The observed levels of high population isolation seem on par with anadromous salmonids, but are unexpected for estuarine and marine organisms. Our results are consistent with previous work on the genetic structure (Bradbury et al. 2008) and morphological divergence (Bradbury et al. 2006b) within these (a) Salmonier River
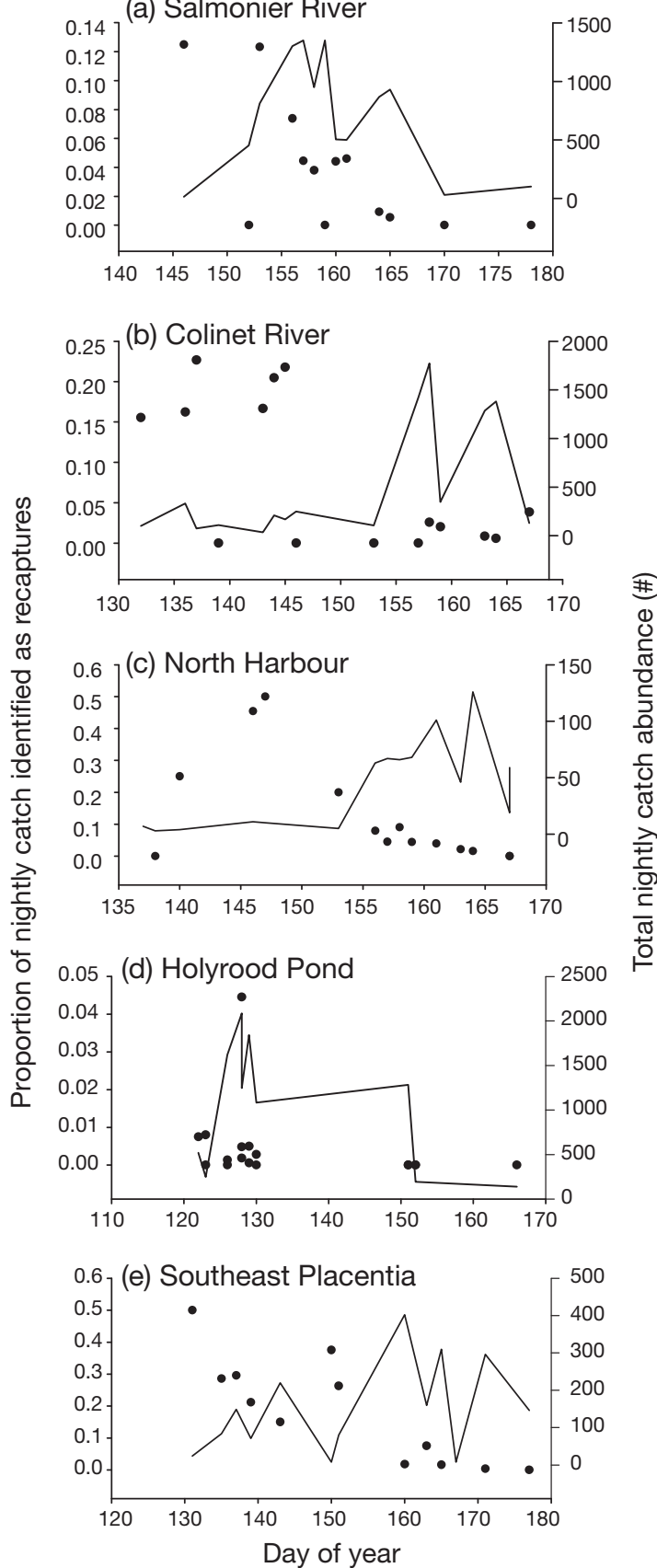

Fig. 8. Osmerus mordax. Temporal distribution of the proportion of total tag returns for each tagging location (closed circles) and overall catch abundance (solid lines) from the VIE tagging experiment in 2005 , at 5 tagging locations (a to e) throughout south-eastern Newfoundland. See Fig. 1 for sample locations

populations. As such, this work supports a hypothesis of estuarine-scale isolation in rainbow smelt and the utility of combining traditional Eulerian tagging studies with otolith-based habitat reconstructions in studies of marine fish spatial dynamics. 
The otolith elemental composition data support the classification of rainbow smelt as an obligate estuarine species (Able 2005). Assignments using the DFA and salinity baselines suggested movements into coastal marine environments $(<1 \%)$ or freshwater $(\sim 11 \%)$ were rare. As such, the majority of growth zones analyzed across adult otoliths indicated an estuarine habitat signature and reinforced evidence of the importance of estuarine habitat throughout the life history of anadromous rainbow smelt. The lack of marine signatures is consistent with discrete populations functioning on the scale of the local estuary. Admittedly, since discrimination between estuarine and marine elemental signatures was $87 \%$, there remains the potential that a small proportion of assays may have been misclassified. This seems unlikely in all but the habitats with elemental signatures most similar to a marine signature (i.e. Biscay Bay and North Harbour). Overall, trends are consistent with estuarine habitat associations and restricted movements.

The use of otolith elemental composition as a measure of ambient salinity and in tracking migrations in diadromous fishes is longstanding (Secor et al. 1995, Limburg 2001, Lamson et al. 2006). We observed significant associations between baseline ambient water and otolith elemental composition ( $\mathrm{Sr}: \mathrm{Ca}$ and $\mathrm{Ba}: \mathrm{Ca})$ consistent with the otolith composition reflecting salinity regimes. Admittedly, temperature may also affect otolith $\mathrm{Sr}: \mathrm{Ca}$, although laboratory experiments suggest the effect due to diadromy is generally an order of magnitude greater than typical temperature influences (e.g. Campana 1999). Interestingly, Ba:Ca also proved useful in discriminating salinity regimes, as has recently been demonstrated by Elsdon \& Gillanders (2005a) in black bream Acanthopagrus butcheri. As such, it seems multi-element signatures may provide greater resolution than single-element approaches, and may be especially useful where elemental gradients are reduced. Potential examples include instances where regional variation in water $\mathrm{Sr}$ :Ca reduces differentiation between freshwater and marine environments (e.g. Kraus \& Secor 2004), or in cases, such as the present study, where reconstructions of transitions between estuaries and coastal waters are of interest.

The utility of otolith elemental composition to reconstruct salinity exposure history depends directly on their reflection of ambient water chemistry and their independence from ontogenetic or physiological processes (Campana 1999). Although it appears the otolith baseline reflects the ambient water composition (see above), we assume our water samples are representative of stable differences between habitats. This seems reasonable given the large differences in salinity among habitats and the observation that these differences are consistent with river, estuarine and marine water samples taken at another time point, as well as the association between baseline water and otolith composition, supports this assumption. In addition, we also assume ontogenetic biases do not influence our assignments. Several studies have documented ontogenetic influences on otolith chemistry (e.g. Toole et al. 1993, Fowler et al. 1995), and comparisons across differing life stages require exploration of these potential biases (Elsdon \& Gillanders 2005a,b). We observed significant differences in Sr:Ca and $\mathrm{Ba}: \mathrm{Ca}$ within otoliths in all 3 of the freshwater baseline samples. However, the presence of any ontogenetic bias did not seem to affect our assignment success, as all freshwater ontogenetic stages were consistently successfully assigned. Admittedly, a similar comparison could be done with a marine baseline to confirm these trends hold irrespective of salinity regime, and we assume that the magnitude of the response would be similar, and, as such, the effect on assignment would be negligible. The validity of this assumption will require future evaluation.

A further limitation is associated with the size of the assay spot in relation to the exposure time of water with differing salinity (e.g. Elsdon \& Gillanders 2005c), and the potential for resolving limited movements among habitats, which may occur on fine temporal scales. We estimate the $25 \mu \mathrm{m}$ spot size corresponds to 3-4 wk of growth on average, and, as such, it is possible that individuals could move between estuaries in time periods below detection limits resulting in an estuarine signature. Using simple mixing equations (e.g. Stewart et al. 2006), we estimate that exposure times of 9 to $12 \mathrm{~d}$ would have been required to generate a marine signature in a fish moving from the estuary into coastal habitats. Movements of this scale are certainly possible for adult smelt, and, as such, this likely represents the limit of our ability to detect marine residency. An obvious future direction would be to characterize the composition of juvenile otoliths in each of these estuaries and subsequently compare them with the juvenile portion of spawning adult otoliths of the same cohorts 2 to $3 \mathrm{yr}$ later. If adequate spatial differences were observed over these small scales, this would give a clear estimate of mixing rates among local estuaries and allow direct comparison with our estimate of marine excursions here.

Our tagging experiments corroborate the otolith elemental results and suggest high levels of multi-year spawning-site fidelity. Observed levels of site fidelity were between 90 and $99 \%$ and were consistent with previous homing rates observed in smelt (McKenzie 1964) and other anadromous salmonids (Hendry et al. $2004)$. The low rates of straying $(<10 \%)$ indicate rela- 
tively low connectivity among estuaries in coastal Newfoundland over small spatial scales $(\sim 30 \mathrm{~km})$. In light of the low number of marine assignments, it seems plausible that few individuals leave local estuaries. Based on the size at age of fish used for elemental analysis, this seasonal drop in average size from 21 to $\sim 19 \mathrm{~cm}$ would seem to correspond to a decline in age of 1 to 2 yr.

The differences between tagging experiments at larger scales was unexpected. Over short distances, both tagging experiments (fin clipping and VIE) resulted in similar declines with distance. However, straying distances in the fin-clipping experiment far exceeded those in the VIE experiment. Nonetheless, movements on par with those observed with the finclipping experiment have been observed in smelt elsewhere, though usually within a single estuary (e.g. McKenzie 1964, Bernatchez \& Martin 1996). Without a direct comparison, it is impossible to comment on the differences between experiments, as they could be related to increased stress of the fin clipping or annual variation in straying rates. However, genetic evidence suggests significant genetic differentiation among these spawning locations $\left(F_{\mathrm{ST}} \approx 0.06\right)$ over scales of 50 to $100 \mathrm{~km}$ (Bradbury et al. 2006b). As such, common long-distance straying at the levels indicated by the fin-clipping experiment seems unlikely, unless there is strong selection against immigrants (i.e. Nosil \& Crespi 2004). Moreover, the otolith elemental data are consistent with the VIE experiment and straying rates of $\sim 1 \%$, though given the smaller sample sizes the power of the otolith data to resolve straying is likely lower than that obtained with tagging approaches. Why the fin-clipping returns suggest significantly increased straying remains unclear. Though it is possible that we are not resolving straying with the otolith element data (see above for discussion) if it occurs in short periods or between neighbouring estuaries (i.e. stepping stone dispersal), it seems likely that straying between bays as suggested by fin-clipping returns over distances of 100 s of kilometres would result in $>0.7 \%$ marine signatures.

High rates of annual returns to isolated estuaries (as indicated by tagging studies) suggest either increased rates of homing associated with discrete estuaries or movements restricted to a single estuary. The otolith elemental data suggest few fish leave the estuary ( $0.7 \%$ marine signatures) and support a hypothesis of restricted movements rather than broad-scale straying and subsequent homing to spawn. A hypothesis of restricted movement is consistent with fall beach seine surveys in the area $(2004,2005,2007)$, which suggest fall and winter occupancy of juvenile and adult smelt in low salinity $(<5$ ppt) waters (Bradbury et al. 2006b, I. R. Bradbury unpubl. data). Previous work on smelt straying supports the observation that straying may be limited and largely confined to within estuaries. McKenzie (1964) observed low rates of straying $(<5 \%)$ among spawning locations in the Miramichi, with no straying outside the estuary. In contrast, Murawski et al. (1980) observed significant mixing indicative of a homogenous spawning population and movements among spawning locations within a season in populations within a single estuary at scales of $<16 \mathrm{~km}$. Similarly, Rupp (1968) noted significant mixing at the time of spawning among spawning locations within a freshwater system at scales of 6 to $7 \mathrm{~km}$. Despite the suggestion of limited movement, work in the St. Lawrence estuary suggests average displacement rates of $150 \mathrm{~km}$, with some as far as $300 \mathrm{~km}$, and a daily displacement of $42 \mathrm{~km} \mathrm{~d}^{-1}$ (Magnin \& Beaulieu 1965). The highest levels of straying were observed among spawning locations within the Holyrood Pond estuary. Here, homing rates to smelt spawning brooks that shared an estuary were $\sim 60 \%$. Our results support the hypothesis that homing behaviour may be less than observed in salmonids, and smelt populations seem largely structured at the estuarine scale.

In anadromous salmonids that display high rates of homing and annual spawning-site fidelity, imprinting during the early life history may allow for returns in subsequent years (e.g. Quinn et al. 2006). As such, homing rates among salmonid species seem to decline with decreased freshwater residency (Hendry et al. 2004). It seems reasonable to hypothesize that homing potential in smelt is limited due to restricted imprinting potential, as larvae are usually transported from the spawning river at hatch (e.g. Bradbury et al. 2004). Indeed, in marine and estuarine fishes with pelagic larvae the potential for imprinting and subsequent homing seems less clear though a few examples exist. Thorrold et al. (2001) estimated natal homing rates of 60 to $70 \%$ in weakfish populations throughout the eastern United States. Robichaud \& Rose (2001) estimated annual spawning-site fidelity of Atlantic cod might be as high as $50 \%$ within coastal populations. Ruzzante et al. (2006) examined genetic structure in herring populations in the eastern Atlantic and suggested that despite extensive mixing, natal homing may significantly contribute to intraspecific diversity. In all cases, individuals were observed to have vacated local estuaries or adult habitats and returned, and the mechanism is clearly spatial homing. The present work illustrates how a combination of multiple tagging approaches (both natural and artificial) may allow the scale of spatial movements to be resolved and true homing behaviour to be differentiated from permanent residency and spawning-site fidelity. 


\section{SUMMARY}

Through a novel combination of Eulerian-based tagging experiments and otolith chemistry-based dispersal reconstructions, we delineate spawning-site fidelity and the extent of non-reproductive movements in a common estuarine fish. We suggest that home ranges for anadromous smelt in coastal Newfoundland seem to be restricted to local estuaries and that smelt metapopulations within Newfoundland are characterized by low connectivity. It seems likely that smelt may be classified as obligate estuarine fish, as suggested by Able (2005), and, as such, the fate of smelt populations may be directly tied to the stability of coastal estuaries, which are increasingly under anthropogenic stresses. We suggest that smelt populations may be unexpectedly susceptible to disturbance in light of the low probability of recovery and recolonization at distances $>50$ to $100 \mathrm{~km}$.

Acknowledgements. The authors thank L. Barrett, who assisted and advised on data analysis and interpretation, as well as R. Hannigan and S. Coghlan at Arkansas State University for their assistance with the otolith elemental composition data collection. This work was supported by a National Sciences Engineering Research Council Strategic Grant and I.R.B. was supported by Postgraduate Scholarship, as well as a Killam Postgraduate Scholarship.

\section{LITERATURE CITED}

Able KW (2005) A reexamination of fish estuarine dependence: a reexamination of connectivity between estuarine and open habitats. Estuar Coast Shelf Sci 64:5-17

Bernatchez L, Martin S (1996) Mitochondrial DNA diversity in anadromous rainbow smelt, Osmerus mordax Mitchill: a genetic assessment of the member-vagrant hypothesis. Can J Fish Aquat Sci 53:424-433

Bradbury IR, Snelgrove PVR (2001) Contrasting larval transport in demersal fish and benthic invertebrates: the roles of behaviour and advective processes in determining spatial pattern. Can J Fish Aquat Sci 58:811-823

Bradbury IR, Snelgrove PVR, Fraser S (2000) Transport and development of eggs and larvae of Atlantic cod, Gadus morhua, in relation to spawning time and location in coastal Newfoundland. Can J Fish Aquat Sci 57:1761-1772

Bradbury IR, Campana SE, Bentzen P, Snelgrove PVR (2004) Synchronized hatch and its ecological significance in rainbow smelt Osmerus mordax in St. Mary's Bay, Newfoundland. Limnol Oceanogr 49:2310-2315

> Bradbury IR, Gardiner K, Snelgrove PVR, Campana SE, Bentzen P, Guan L (2006a) Larval transport, vertical distribution, and localized recruitment in anadromous rainbow smelt (Osmerus mordax). Can J Fish Aquat Sci 63: 2822-2836

Bradbury IR, Coulson M, Campana SE, Bentzen P (2006b) Morphological and genetic differentiation in anadromous rainbow smelt: disentangling the effects of geography and morphology on gene flow. J Fish Biol 69:95-114

Bradbury IR, Campana SE, Bentzen P (2008) Low genetic connectivity in an estuarine fish with pelagic larvae. Can J
Fish Aquat Sci 65:147-158

$>$ Campana SE (1999) Chemistry and composition of fish otoliths: pathways, mechanisms and applications. Mar Ecol Prog Ser 188:263-297

Campana SE (2005) Otolith elemental composition as a natural marker of fish stocks. In: Cadrin SX, Friedland KD, Waldman JR (eds) Stock identification methods. Academic Press, New York, p 227-245

Campana SE, Chouinard GA, Hanson JM, Frechet A (1999) Mixing and migration of overwintering Atlantic cod (Gadus morhus) stocks near the mouth of the Gulf of St. Lawrence. Can J Fish Aquat Sci 56:1873-1881

Catalano MJ, Chipps SR, Bouchard MA, Wahl DH (2001) Evaluation of injectable fluorescent tags for marking centrarchid fishes: retention rate and effects on vulnerability to predation. N Am J Fish Manage 21:911-917

Coghlan SM, Lyerly MS, Bly TR, Williams JS, Bowman D, Hannigan R (2007) Otolith chemistry discriminates among hatchery-reared and tributary spawned salmonines in a tailwater system. N Am J Fish Manage 27:531-541

- Elsdon TS, Gillanders BM (2003) Relationship between water and otolith elemental concentrations in juvenile black bream Acanthopagrus butcheri. Mar Ecol Prog Ser 260: $263-272$

> Elsdon TS, Gillanders BM (2005a) Alternative life-history patterns of estuarine fish: barium in otoliths elucidates freshwater residency. Can J Fish Aquat Sci 62:1143-1152

> Elsdon TS, Gillanders BM (2005b) Consistency of patterns between laboratory experiments and field-collected fish in otolith chemistry: an example and applications for salinity reconstructions. Mar Freshw Res 56:609-617

> Elsdon TS, Gillanders BM (2005c) Strontium incorporation into calcified structures: separating the effects of ambient concentration and exposure time. Mar Ecol Prog Ser 285: 233-243

> Fowler AJ, Campana SE, Jones CM, Thorrold SR (1995) Experimental assessment of the effect of temperature and salinity on elemental composition of otoliths using solution-based ICPMS. Can J Fish Aquat Sci 52:1421-1430

Gillanders BM (2005) Using element chemistry of fish otoliths to determine connectivity between estuarine and coastal habitats. Estuar Coast Shelf Sci 64:47-57

> Hamer PA, Jenkins GP, Gillanders BM (2005) Chemical tags in otoliths indicate the importance of local and distant settlement areas to populations of a temperate sparid, Pagrus auratus. Can J Fish Aquat Sci 62:623-630

Harden Jones FR (1968) Fish migration. Edward Arnold Press, London

Hastings A, Botsford LW (2006) Persistence of spatial populations depends on returning home. Proc Natl Acad Sci USA 103:6067-6072

Hendry AP, Castric V, Kinnison MT, Quinn TP (2004) The evolution of philopatry and dispersal. In: Hendry AP, Stearns SC (eds) Evolution illuminated: salmon and their relatives. Oxford University Press, Oxford

Jones GP, Planes S, Thorrold S (2005) Coral reef fish larvae settle close to home. Curr Biol 15:1314-1318

Kraus RT, Secor DH (2004) Incorporation of strontium into the otoliths of an estuarine fish. J Exp Mar Biol Ecol 302:85-106

- Lamson HM, Shiao J, Iizuka Y, Tzeng W, Cairns DK (2006) Movement patterns of American eels (Anguilla rostrata) between salt- and freshwater in a coastal watershed, based on otolith microchemistry. Mar Biol 149:1567-1576

> Laprise R, Dodson JJ (1989) Ontogeny and importance of tidal vertical migrations in the retention of larval smelt Osmerus mordax in a well-mixed estuary. Mar Ecol Prog Ser 55:101-111 
Limburg KE (2001) Through the gauntlet again: demographic restructuring of American shad by migration. Ecology 82:1583-1596

Magnin E, Beaulieu G (1965) Quelques données sur la biologie de l'Éperlan Osmerus eperlanus mordax (Mitchill) du Saint-Laurent. Nat Can 92:81-105

Martin GB, Wuenschel MJ (2006) Effect of temperature and salinity on otolith element incorporation in juvenile gray snapper Lutjanus griseus. Mar Ecol Prog Ser 324:229-239

McKenzie RA (1964) Smelt life history and fishery in the Miramichi, New Brunswick. Bull Fish Res Board Can 144:1-77

Murawski SA, Clayton GR, Reed RJ, Cole CF (1980) Movements of spawning rainbow smelt, Osmerus mordax, in a Massachusetts estuary. Estuaries 3:308-314

Nellbring S (1989) The ecology of smelts (genus Osmerus): a literature review. Nord J Freshw Res 65:116-145

Nosil P, Crespi BJ (2004) Does gene flow constrain adaptive divergence or vice versa? A test using ecomorphology and sexual isolation in Timema cristinae walking sticks. Evolution 58:102-111

Ouellet P, Dodson JJ (1985) Dispersion and retention of anadromous rainbow smelt (Osmerus mordax) larvae in the middle estuary of the St. Lawrence River. Can J Fish Aquat Sci 42:332-341

Palumbi SR (2004) Marine reserves and ocean neighborhoods: the spatial scale of marine populations and their management. Annu Rev Environ Resour 29:31-68

Quinn TP, Stewart IJ, Boatright CP (2006) Experimental evidence of homing to site of incubation by mature sockeye salmon, Oncorhynchus nerka. Anim Behav 72:941-949

Roberts JH, Kilpatrick JM (2004) Predator feeding preferences for a benthic stream fish: effects of visible injected marks. J Freshw Ecol 19:531-537

Initial editorial responsibility: Howard Browman, Storebø, Norway; Final editorial responsibility: Matthias Seaman,

Oldendorf/Luhe, Germany
Robichaud D, Rose GA (2001) Multiyear homing of Atlantic cod to a spawning ground. Can J Fish Aquat Sci 58: 2325-2329

Rupp RS (1968) Life history and ecology of smelt (Osmerus mordax) in the inland waters of Maine. Final report, Dept. Inland Fish and Game, Portland, ME

Ruzzante DE, Mariani S, Bekkevold D, André C and others (2006) Biocomplexity in a highly migratory pelagic marine fish, Atlantic herring. Proc R Soc Lond B Biol Sci 273: 1459-1464

Secor DH, Rooker JR (2000) Is otolith strontium a useful scalar of life-cycles in estuarine fishes? Fish Res 46:359-371

Secor DH, Henderson-Arzapalo A, Piccoli PM (1995) Can otolith microchemistry chart patterns of migration and habitat utilization in anadromous fishes? J Exp Mar Biol Ecol 192:15-33

Shanks AL, Grantham BA, Carr MH (2003) Propagule dispersal distance and the size and spacing of marine reserves. Ecol Appl 13:159-169

Stewart REA, Campana SE, Jones CM, Stewart BE (2006) Bomb radiocarbon dating calibrates beluga (Delphinapterus leucas Pallas, 1776) age estimates. Can J Zool 84: 1840-1852

Thorrold SR, Jones CM, Campana SE (1997) Response of otolith microchemistry to environmental variations experienced by larval and juvenile Atlantic croaker (Micropogonais undulatus). Limnol Oceanogr 42:102-111

Thorrold SR, Latkoczy C, Swart PK, Jones CM (2001) Natal homing in a marine fish metapopulation. Science 291: 297-299

Toole CL, Markle DF, Harris PM (1993) Relationships between otolith microstructure, microchemistry, and early life history events in Dover sole, Microstomus pacificus. Fish Bull 91:732-753

Submitted: February 23, 2007; Accepted: May 22, 2008 Proofs received from author(s): September 19, 2008 